\title{
Do Ghanaians Prefer Imported Textiles to Locally Manufactured Ones?*
}

\author{
Peter Quartey ${ }^{1}$, Joshua Abor ${ }^{2}$ \\ ${ }^{1}$ Institute of Statistical, Social and Economic Research, University of Ghana, Legon, Ghana \\ ${ }^{2}$ Department of Finance, University of Ghana Business School, Legon, Ghana \\ E-mail:pquartey@ug.edu.gh \\ Received October 2, 2010; revised October 20, 2010; accepted October 26, 2010
}

\begin{abstract}
This paper ascertains whether consumers prefer locally made textile to imported ones or vice versa and what accounts for the choice. The study uses survey data of industry, traders and consumers to explain the issue. The results show that most consumers prefer locally-made textiles to imported ones. More than half of those who prefer locally-made textiles claimed local textile products are of a better quality. Others claimed they are more affordable and attractive while a few claimed local textiles are cheaper. This appears to contradict the country-of-origin effect and the results of previous studies in Africa and other developing countries. Implications for traders, governments and local manufacturers are also discussed. The study provides insights with respect to Ghanaians' preference of locally-produced textiles to foreign-made ones.
\end{abstract}

Keywords: Country-of-Origin, Imports, Ghana

\section{Introduction}

Ghana's current trade policy, which aims at promoting accelerated economic development and reducing poverty, supports two parallel strategies, namely, export-led industrialization and domestic market-led industrialization based on import competition. The success of both strategies depends on the competitiveness of local producers in both the domestic and international markets. For some years now, import competing industries have been facing a number of challenges which are alleged to have inhibited their growth [1]. The key factors usually noted as being responsible for aggravating the situation have included the inflow of un-customed goods through unfair trading practices, infringement on intellectual property rights and the importation of imitation products that may usually carry lower prices to mention but a few. Local manufacturers of textiles in particular, are those significantly affected by these developments.

For instance, while in the mid 1970's, the textile industry's production capacity was approximately 130 million metres and employed about 25,000 workers; by 2002 , production capacity and employment levels had dropped to 36 million metres and 2,000 workers respec-

*This study was funded partially by the Think Tank Initiative (TTI) Core Grant provided by IDRC to ISSER. tively [2]. In some African countries where this has happened, governments have responded to reverse the declining trend. For instance, the Federal Government of Nigeria in September 2002 took various drastic measures which included a total ban on importation of all finished textiles in order to assist the Nigerian Textile Industry and save it from total collapse. Thus, while the textile industries in Nigeria enjoy duty incentive of $10 \%$, export expansion grant of $30 \%$ and; $0 \%$ Value Added Tax (VAT) and National Health Insurance Levy (NHIL), Ghanaian industries have no duty incentives and export expansion grant, but rather are made to pay a $12.5 \%$ VAT and $2.5 \%$ NHIL on their finished products, thereby, making Ghana's products more expensive.

The limited incentive structure has led to unemployment, loss of government revenue and loss of access to the African Growth and Opportunity Act (AGOA). Local producers of textiles have identified some 'safeguard options' in the World Trade Organization (WTO) stipulations such as Bi-lateral negotiations to limit exports, emergency measures to limit imports and countervailing duty which Ghana can take advantage of. Stakeholders have advocated for certain measures to revive the textiles sector, namely, removal of duty on inputs for the production process; increase in duty on finished fabrics imported; proper collection of duties and taxes on imports; 
seizure of goods which are found to be undervalued, misrepresented, pirated, copied or sub-standard. Ironically, while the job losses continue and stakeholders continue to advocate for a ban on imported textile, Ghanaians continue to patronize imported textile products. One may therefore ask, why do Ghanaians continue to import these products at the expense of local substitutes? Could price or quality be a factor? These issues remain the focus of investigation in this report.

This paper uses survey data of industry, traders and consumers to explain whether consumers prefer locally made textile to imported ones or vice versa and what accounts for the choice. The rest of the paper is organized as follows: section two presents the stylized facts on the textile and clothing industry in Ghana. The third section provides a brief overview of extant literature. Section four discusses the research findings in terms of whether Ghanaians prefer locally made textile products to imported ones and if so what were the major reasons. The final section provides concluding remarks and draws the policy implications of the study.

\section{The Textile Industry in Ghana}

As at mid 1970's, about 16 large $^{1}$ and medium sized textile companies had been established in Ghana. The garment industry also had some 138 medium and large-scale garment manufacturing companies during that time. However, inconsistent government policies over the years have contributed greatly to the decline in the subsector's activity levels. As at 2002, the four major companies that survived the turbulence in the sub-sector were the Ghana Textile Manufacturing Company (GTMC), Akosombo Textile Limited (ATL), Ghana Textile Product (GTP), and Printex with GTP maintaining the lead in the industry. The garment industry comprised of numerous small-scale enterprises which took the form of sole proprietorship and were engaged in making garments for individuals as well as uniforms for schools, industries and governmental institutions such as the police, the army, hospitals, etc, and also for the exports market. The garment industry however, depended directly on the textile industry. Investments within the textile industry were mainly by local firms. A survey of 40 textile and garment industries within Accra-Tema revealed that only 5\% of these firms were involved in joint ventures with foreign investors. The rest (95 percent) were locally-owned and

\footnotetext{
${ }^{1}$ Size categories: small-scale (has 5-29 employees), medium-sized (has 30-99 employees), large-scale (employs 100 or more people)

${ }^{2}$ About 44 percent of industry respondents have cut down on employment. From the total number of firms that had shed staff, 59 percent have laid off up to 5 percent of their workforce, 24 percent laid off up to $6-10$ percent and 11 percent have cut down employment by over 70 percent between 2000 and 2005 .
}

none was solely foreign owned.

Ghana's textile industry employed about 25,000 people and accounted for 27 percent of total manufacturing employment in 1977. However, by 1995 employment within the sub-sector declined to a mere 7,000 and declined further to 5000 by the year 2000 [3]. The declining trend has not changed and employment continues to decline. As at March 2005, the four major textile companies in Ghana employed a mere 2961 persons [4]. A survey of 40 textile and garments industries in 2007 also confirmed that the situation is getting worse ${ }^{2}$.

Ghana's textile industry is mainly concerned with the production of fabrics for use by the garment industry and also for the export market. The sub-sector is predominantly cotton-based although the production of manmade fibres is also undertaken on a small scale. The main cotton-based textile products include: African prints (wax, java, fancy, bed sheets, and school uniforms) and household fabrics (curtain materials, kitchen napkins, diapers and towels). These products form the core of the sub-sector. The main products of the man-made fibres (synthetics) and their blends include: uniforms, knitted blouses, socks etc. These are mainly made from polyester, acrylic and other synthetics. There are also a number of small firms hand-printing their designs into bleached cotton fabrics, also known as tie and dye or batik cloth. Also, traditional or indigenous textiles such as Kente cloth (traditional woven fabric), Adinkra cloth (traditional hand printing fabric) and other types of woven fabrics used for various purposes such as smock making etc. are proposed.

Total industry output peaked at 129 million yards in 1977 with capacity utilization rate of about 60 percent. GTP maintained the lead in the industry with an annual production of 30.7 million yards (includes the outputs of Juapong and Tema plants). This was followed by GTMC, ATL, and Printex with production levels of 15 million, 13 million and 6 million yards respectively. Unfortunately, total industry output declined from its 1970 level to 46 million yards in 1995 but recovered to 65 million yards in 2000. As at March 2005, GTP was producing 9 million yards, ATL 18 million yards GTMC 2.24 million yards and Printex 9.84 million yards. A total annual output of 39.04 million yards was produced by the industry as at March 2005, which translates to an average of $49.4 \%$ of initially installed capacity of the four firms. Thus output had declined from 65 million yards in 2000 to 39 million yards in 2005 (see Table 1).

A recent survey of textile and garment firms in AccraTema indicated that firms have cut down significantly on output, in fact, more than half (about 75 percent) of textile and garment manufacturers answered in the affirmative. About 7 percent of this number indicated that they 
had reduced output by up to $20 \%$. A further 32 percent indicated their output reduced by 21-30 percent. About 21 percent had reduced production by $31-40$ percent while 11 percent have had their output reduced by 41-50 percent and a further 4 percent had recorded over 50 percent fall in output. The rest ( 25 percent) could not tell by how much they have cut down on production. The reasons for the decline in output are varied.

The survey respondents offered several reasons for cutting down on production; about 44 percent of the manufacturers who claimed they have cut down on production cited low demand for local textile products as the principal reason necessitating their action; while 15 percent also mentioned high cost of production and 11 percent cited high wage bills resulting in their inability to pay workers. Another 15 percent blamed the problem largely on the influx of imitated products from abroad, particularly Asia and Cote d'Ivoire. Others mentioned smuggling and dumping (7 percent) as well as lack of raw materials (4 percent).

Imports of textile have grown steadily over the years. In 1992, the country imported US \$35 million worth of fabrics and garments. This increased to US\$ 57 million in 1998 and by the first half of 1999, US\$ 42 million worth of fabrics and garments had been imported (MOTI, 2002). It is estimated that at the end of the first quarter of 2005 , imported textile prints will have accounted for $48 \%$ of total textile prints in the Ghanaian market (Ghana Employers Association, 2005). The local market is facing stiff competition from finished imported textile prints such as calico, grey baft, furnishing materials usually from Cote d'Ivoire, Nigeria, China, and most recently from India and Pakistan. Consumers have argued that although the locally produced finished fabrics are relatively better in terms of quality, the market for imported products has increased because the products have attractive colours, new designs, a softer and glossier finish. Table 1 indicates the trend in imported fabrics from
1997-2000

\subsection{Importance of Textile Exports to Ghana's Economy}

The use of textiles in Ghana is a way of life and it is rooted in historical and cultural antecedents. They are used for funerals, naming ceremonies, church service, and official functions, to name but a few. Textile exports are an important source of foreign exchange and revenue to textile manufacturing firms. Textile exports generated \$27.2 million in 1992 and this increased to \$179.7 million in 1994 but revenue from exports declined consistently thereafter and by 1998 , they had fallen to $\$ 3.173$ million. It is worth mentioning that in 2000, Ghana qualified for AGOA; and exports of Ghanaian textile and apparel to the US market amounted to $\$ 550,000$ in 2002 , $\$ 4.5$ million in 2003 and $\$ 7.4$ million in 2004. Imports of US textile and apparel were $\$ 8.87$ million, $\$ 12.73$ million and $\$ 11.48$ million respectively over the same period (http://www.agoa.info).

The decline in textile exports from 1992 to 1998 (see Table 2) can be attributed to internal and external bottlenecks. Ghanaian manufacturers of textiles generally agree that the market for exports is huge, but have reservation about operating in some of these markets particularly within the ECOWAS sub-region due to trade barriers. Some of the trade barriers include among others, imposition of $20 \%$ duty by Cote d'Ivoire (contrary to ECOWAS regulations), transit tax collected at Benin, extortion by Nigerian authorities, and the risk of currency devaluation. Poor packaging by some manufacturers/exporters also serves as a barrier to exports to markets such as the EU and the United States of America. Also, poor finishing of products (quality/conformity to standards), technical barriers, inability of some manufacturers to meet export orders on schedule, high tariffs

Table 1. Textile imports by type.

\begin{tabular}{ccccccc}
\hline \multirow{2}{*}{ Year } & \multicolumn{2}{c}{ Wax Print } & \multicolumn{2}{c}{ Java/Fancy \& the similar print } & \multicolumn{2}{c}{ Calico (Bleached Fabric) } \\
\cline { 2 - 7 } & Qty/Vol. (Kg) & US\$ (000) & Qty/Vol. (Kg) & US\$ (000) & Qty/Vol. (Kg) & US\$ (000) \\
\hline 1997 & 30,775 & 106 & 152,300 & 406 & 9,418 & 41 \\
1998 & 11,423 & 571 & 46,881 & 204 & 80,138 & 601 \\
1999 & 86,700 & 2,318 & 136,634 & 477 & 182,091 & 1,044 \\
2000 & 135,197 & 1,313 & 455,764 & 1,818 & $1,034,978$ & 5,247 \\
\hline
\end{tabular}

Source: MOTI, 2002

Table 2. General textile fabric imports \& exports (excluding AGOA).

\begin{tabular}{lcccccccc}
\hline & 1992 & 1993 & 1994 & 1995 & 1996 & 1997 & 1998 & 1999 \\
\hline Exports US\$ million & 27.18 & 76.7 & 179.7 & 7.703 & 3.429 & 5.074 & 3.173 & na \\
Imports US\$ million & 34.57 & 38.28 & 39.40 & 42.30 & 53.35 & 52.65 & 56.55 & $42.29^{3}$ \\
\hline
\end{tabular}

Source: MOTI, 2002

${ }^{3}$ Half-year figure. 
charged in some export destinations of Ghanaian textiles ${ }^{4}$ are among the barriers to exports to external markets.

The main export destination for made-in-Ghana textiles as at 2004 included EU countries (55\%), the U.S. (25\%), and ECOWAS (15\%). The remaining 5 percent are exported to other countries, mostly Southern and East African states (mainly South Africa, Zimbabwe, Namibia, Ethiopia etc). Textile and garment exports from Ghana comprise fancy prints, wax prints, Java prints, calico smock, ladies dresses, men's wear, etc. The indigenous textile products like Kente, a special fabric produced on a traditional loom, Adinkra (hand prints) and smock or fugu are also exported. Batik or tie and dye fabrics are also used to produce all kinds of products for the export markets. These products include: a unique brand of carefully crafted handbags, casual wear for ladies and gentlemen, shirts, dresses; napkins, cushion covers, bedspreads, chair backs, curtains, toys and many others.

\section{Brief Overview of Literature}

The country-of-origin effect has been identified as an important factor explaining customers' product preference [5-7]. Reference [8] define country-of-origin image as how a product designed, manufactured, or branded in a developed country is perceived in a developing country. Reference [9] argues that the country of manufacture and product quality strongly influence consumer decision making in globally available product categories.

The extant empirical literature from developed countries suggests that consumers in those countries tend to prefer products from developed countries to those from less developed countries $[10,11]$. They explain that consumers prefer products from their own countries first, followed by products from other developed countries before considering those from other countries. Normally (in Mexico), consumers tend to have a preference for local products in countries where there is strong patriotism, national pride, or consumer ethnocentrism [12]. Reference [9] also suggests that consumers prefer domestically manufactured goods and are willing to pay higher price for them. It is only when imported goods are of a significantly superior quality that consumers will move to obtain those.

With respect to developing countries, the existing literature suggests that customers prefer western to domestic products. Reference $[13,14]$ for instance found that consumers in the former socialist countries of eastern and central Europe prefer western to domestic products.

\footnotetext{
${ }^{4}$ The survey of 40 textile manufacturers cited transit taxes as the major constraint to exports (about 29\%), followed by haulage and high transport cost ( 24 percent), extortion at the borders (12 percent), and poor infrastructure (12 percent). About 18 percent cited some other problems.
}

Reference [14] showed that the price effect was not as important as the country-of-origin effect in explaining customer choice in Russian, Polish and Hungarian. Reference [11] reported that Mexicans have a poor perception of local products and they tend to rate American and Thailand household electronic products above Mexicanmade brands. Reference $[15,16]$ also explain that high income levels in Mexico account for more preference for foreign goods. Reference [17] reported that there is a great demand for western consumer goods among Indian consumers. In a study in Czech, Reference [18] found that customers had a preference for German products as compared to products from the Czech Republic. Reference [19] found that Bangladeshi consumers significantly preferred western-made products, though there were differences in their perceptions across product classes as well as degree of suitability of sourcing countries. In a Chinese study, Reference [20] showed that there was huge preference for western products among the Chinese people. A study by Reference [21] also revealed that the elite in Pakistan consider country of origin of products in taking purchasing decisions.

A number of studies have also been carried out in African countries with respect to the country-of-origin effect. Reference [22] argues that, in economically underdeveloped countries, preference for domestic products tends to be weaker. Reference [23], in a Nigerian study, found that the Nigerian consumer obsession with foreign-made goods has had a detrimental effect on the domestic manufacturing industry. They found that the country-of-origin is significantly more important than price and other product attributes in consumer preference. Nigerian consumers have a negative image of the 'Made in Nigeria' label, rating it lower than labels from more economically developed countries. They also found that the superior reliability and technological advancement of foreign products are the most important correlates of the Nigerian consumer's likelihood to purchase foreign products. Reference [24] examined the impact of country-of-origin effects and consumer attitudes towards buy local campaign initiatives. They found that, the attitudes of consumers to buy locally-made campaigns can be characterized as protectionist, nationalistic, and self-interest seeking.

In a study on five West African countries, Reference [25] investigated the country-of-origin effects in service evaluation and found that situational personal characteristics, such as motivation and ability to process information, may influence use of country-of-origin attributes in evaluating a service. Besides, individual characteristics, such as ethnocentrism and culture orientation, may influence country-of-origin preference in service evaluation. In a Ghanaian study, Reference [8] examined con- 
sumer attitudes towards local and imported products in a developing country market. They found that the country-of-origin of the products is more important than price and other product attributes. They showed that the Ghanaian consumer holds the 'Made in Ghana' label in low regard relative to foreign labels, whilst superior quality and con- sumer taste are the second most important reasons for the Ghanaian consumers' preference for foreign products.

Clearly, the empirical literature suggests that consumers consider products from developed countries more favourably than those from less-developed and developing countries. Following from this hypothesis, this study is therefore positioned to ascertain Ghanaians' preference for imported textiles to locally manufactured ones. This present study focuses on consumers, traders and manufacturers of textiles, unlike the study by Reference [8] which concentrated on only customers of rice, clothing and textiles.

\section{Do Consumers Prefer Locally Manufactured Textile to Imported Ones?}

The study used secondary as well as primary data on textile production, imports and consumption in Ghana. A total of 40 manufacturers of textiles in Accra, 40 consumers of textile products as well as 40 traders of textiles located in the business district of Accra were interviewed in 2007 using a structured questionnaire for each group of respondents. The study adopted a snow ball sampling technique in selecting respondents from the markets and face-to-face interviews were conducted. There is no exact number of textile traders in Ghana but we believe their views will not vary widely across the country. Thus, 40 traders were selected in view of the perceived homogeneity of most textile traders. The manufacturers selected included the four major textile traders in addition to other small-scale operators.

Most of the respondents (traders) were women and above 51 years. This confirms the perception that trading in textiles is a preserve for women, who are mainly found in popular market centres such as the Makola Market in the city of Accra, Ghana. As expected, most (a quarter) of the traders have had little or no formal education. This reflects the characteristics of the informal private sector in Ghana. In terms of age, out of the 40 consumers of textiles interviewed, only 3 percent of the respondents were below 20 years while 60 percent of total respondents were within the 20-50 years and 2.5 percent were above 51 years.

Trading in textiles seems to be a very active business; the majority ( 55 percent) of the respondents indicated they buy textile products weekly while about a quarter (22.5 percent) of them said they buy textile products monthly. Only 10 percent of them buy textile products fortnightly. This is an indication of high turnover of stock among textile traders and all things being equal, traders should earn appreciable level of margins.

\subsection{Preference for Local or Imported Textiles}

Concerning taste and preference, interviews with traders of textiles revealed strong preference for locally made textiles. More than half (53 percent) of the respondents indicated a strong preference for local textile products while 40 percent preferred imported textile products. The rest ( 7 percent) were indifferent. Figure 1 presents traders preferences for textiles. This finding tends to contradict the country-of-origin effect and the results of previous studies in Africa and other developing countries.

For those who said they preferred buying and selling imported textile products, about 26 percent of them indicated that imported textiles are quite affordable, 21 percent believed they are more profitable, about 11 percent thought they are attractive. Only 5 percent claimed imported textiles are of good quality while the rest (37 percent) could not assign any reason for their strong preference for imported textiles. About 42 percent of the respondents cited high prices for local textiles while about 22 percent cited low demand for local textiles. About 15 percent mentioned low turnover of local textile products.

About 55 percent of consumers indicated that they buy textile products occasionally while 24 percent claimed they buy them annually. About 10 percent often buy textile products monthly and 2 percent often buy them weekly. The rest usually buy them quarterly and bi-annually (see Figure 2). This is an indication that, textiles are mainly for occasional days such as naming ceremonies, funerals, engagement and festivals in Ghana.

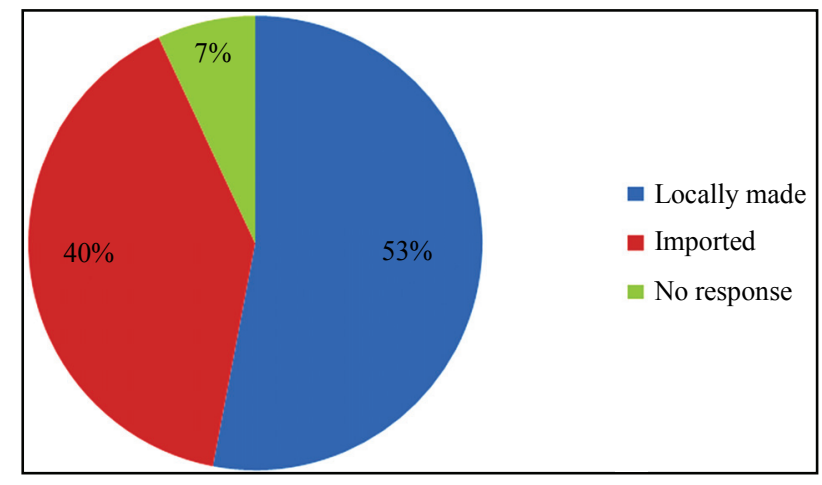

Source: Survey Data, 2007

Figure 1. Consumer preferences. 
As shown in Figure 3, more than half of those who prefer locally made textile products (53 percent) claimed local textile products are of good quality (this represents 40 percent of total sample). Others claimed they are affordable (17 percent), attractive (20 percent) while the rest ( 7 percent) claimed local textiles are cheap.

\subsection{Ban on Imported Textiles}

With respect to respondents' views on placing a ban on imported textiles, some of them (35 percent) indicated that textiles imported into Ghana should be banned. About 65 percent of them did not support a ban (see Figure 4).

For those who thought imported textiles should be banned, about 43 percent of them were of the view that the ban would promote the local textile industry, about 31 percent thought the ban could help the local industry generate more employment. The rest, 23 percent believed the ban could salvage the local textile industry. According to those who did not support the ban on imported textiles, about 46 percent claimed they are cheap and affordable. About 18 percent of the respondents claimed they are profitable while 11 percent thought they are of superior quality. Almost 70 percent of respondents expected to see a reduction in the price of local textile products, while 22 percent of them expected to see improvement in quality and attraction of local textile products. The rest advocated for a reduction in taxes and avoidance of favouritism.

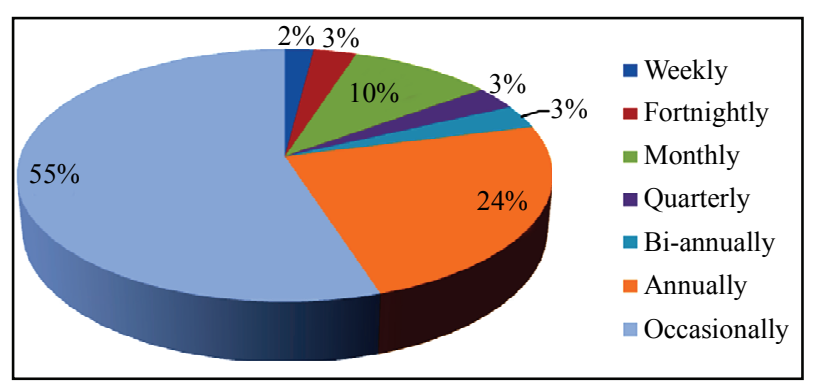

Source: Survey data

Figure 2. Frequency of purchase.

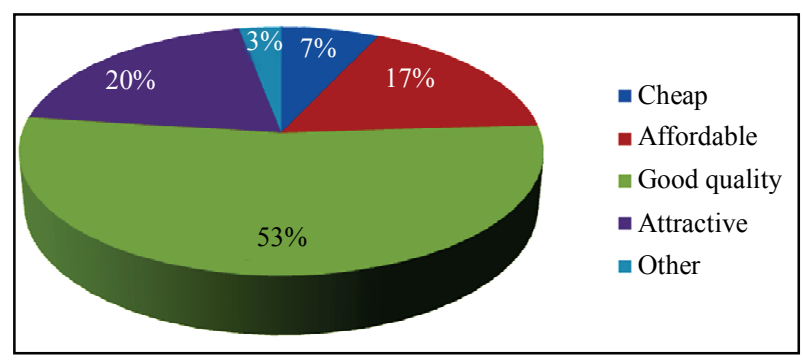

Source: Survey data

Figure 3. Reasons for textile preferences.

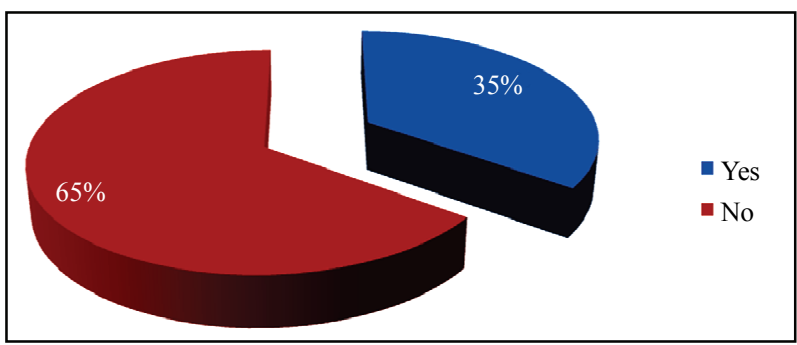

Source: Survey data, 2007

Figure 4. Ban on imported textile.

\subsection{Comparing Quality}

Comparing the quality of imported textile products with local textile products, majority of consumers (48 percent) claimed imported textile products are better, while 27 percent went for local textile products. Only 5 percent thought they are of the same quality, while 20 percent were indifferent (see Figure 5).

\subsection{Policy Changes}

Most of the traders stressed the need for a reduction or removal of taxes on imported raw materials. Other policy recommendations include giving the products to traders on credit, imposing heavier taxes on imported textiles, placing a ban on imported textiles, making local textile products affordable, and promoting wearing of local textile products. For example, 37 percent suggested a reduction in taxes on imported raw materials, another 27 percent advocated for marketing and promotion of local textiles. About 13 percent thought subsidies should be given to the local textiles industry. Only 13 percent however, called for a total ban on imported textile products (see Figure 6).

\section{Conclusions and Policy Implications}

This study investigated whether consumers prefer locally-made textile products to imported ones and if so, why? The approach involved the use of micro and macro data. The macro data was obtained from the Ministry of Trade and other relevant literature. The micro data was

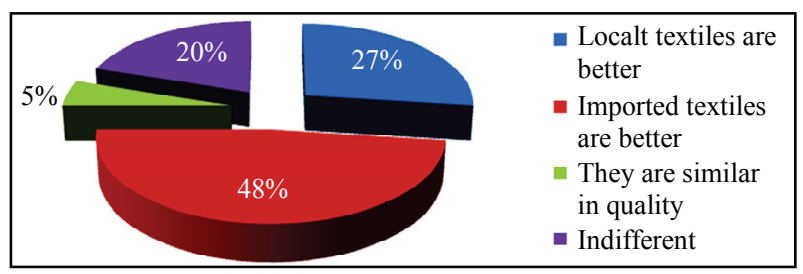

Source: survey data

Figure 5. Quality comparison. 


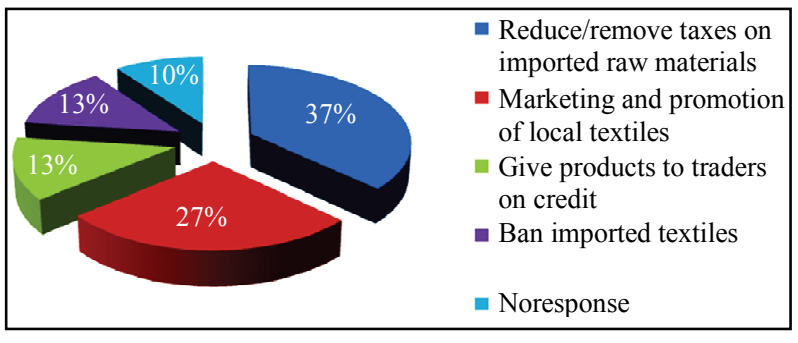

Source: Survey data

Figure 6. Expected policy changes (traders).

obtained from a survey of 40 textile and clothing manufacturers in Accra, 40 consumers and an equal number of traders located in the business districts of Accra. The study made very useful revelations. The key findings of the study show that, most consumers prefer locally-made textiles to imported ones, contrary to the country-of-origin effect.

Nearly two decades after independence, the textile sub-sector was the major key player in Ghana's Industrial sector, contributing significantly to employment and growth in the economy. However, the sub-sector which was once the leader in Ghana's industrial sector has undergone a considerable decline over the years, largely due to the liberalisation programmes which made it almost impossible for Ghana's textile products to compete with the cheap imports, particularly from Asia.

It is however estimated that the few companies that managed to survive operated at just about 5 percent installed capacity since 1995 . Various reasons have accounted for the decline. Some of the major ones mentioned include: low demand for local textile products and influx of second hand clothing; lack of competitiveness of local textiles against imported textiles due to high cost of local textiles which resulted from high cost of production ${ }^{5}$; and smuggling.

In view of the current crisis faced by the industry, its outlook remains bleak and therefore calls for pragmatic polices that will lead to both local and global restructuring of the industry. Locally, it is necessary that concrete steps are taken to address the problem of cheap imports, under-declared imports, wrongly described textile imports, and copied brands, markings, tickets and labels lead to the recent proposal by government to establish an Economic Intelligence Unit, including the Ghana Standards Board, to arrest and punish those engaged in trade malpractices. In this Economic Intelligence Unit to arrest and punish those engaged in trade malpractices is timely. The penalty for those culprits engaging in these malpractices should be severe to serve as a deterrent to other

${ }_{5}^{5}$ Due to high cost of local cotton, obsolete plants and machinery, high cost of utilities, overstaffing, high cost of finance (high interest rate) etc. perpetrators of the crime. Secondly, the unit should be proactively and effectively managed; otherwise, arresting the perpetrators will prove elusive.

On the global scene, trade negotiations and fair trade practices, particularly, within the textile and garments sub-sector should be made explicit and adhered to. Instances of copying brands and other product markings from other countries should be discouraged. This should go together with fair trade practices and preferential access to markets in developed countries.

\section{References}

[1] P. Quartey, "The Textile and Clothing Industry in Ghana," In: H. Jauch and R. Traub-Merz, Eds, The Future of the Textile and Clothing Industry in Sub-Saharan Africa, Bub Bonner Universitats-Buckdruckerei, Germany, 2006, pp. 135-146.

[2] Ministry of Trade and Industry, "Study of the Textile Sub-sector," A Report Prepared by Brucks \& Associates for MOTI, November 2002.

[3] V. O. Ampofo, "Ghana's Textile and Garment Industry," Ministry of Trade and Industry, Industrial Development and Investment Division, 2002.

[4] Ghana Employers Association, "Measures to Save the Textile Industry in Ghana," A Report Prepared by the Sub-Committee of the National Tripartite Committee on Measures to Save Ghana's Textile Industry, March 2005.

[5] J. Agrawal and W. A. Kamakura, "Country of Origin: A Competitive Advantage?" International Journal of Research in Marketing, Vol. 16, No. 4, 1999, pp. 225-267. doi:10.1016/S0167-8116(99)00017-8

[6] P. W. J. Verlegh and B-EM Steenkamp, "A Review and Meta-Analysis of Country of Origin Research," Journal of Economic Psychology, Vol. 20, No. 5, 1999, pp. 521546. doi:10.1016/S0167-4870(99)00023-9

[7] S. Bhaskaran and N. Sukumaran, "Contextual and Methodological Issues in COO Studies," Marketing Intelligence and Planning, Vol. 25, No. 1, 2007, pp. 66-81. doi:10.1108/02634500710722407

[8] R. A. Opoku and P. A. K. Akorli, "The Preference Gap: Ghanaian Consumers' Attitudes toward Local and Imported Products," African Journal of Business Management, Vol. 3, No. 8, 2009, pp. 350-357.

[9] G. A. Knight, "Consumer Preference for Foreign and Domestic Products," Journal of Consumer Behaviour, Vol. 16, No. 2, 1999, pp. 1-11.

[10] C. K. Wang and C. Lamb, Jr., "The Impact of Selected Environmental Forces upon Consumers' Willingness to Buy Foreign Products," Journal of the Academy of Marketing Science, Vol. 11, No. 2, 1983, pp. 71-94. doi:10.1007/BF02721862

[11] E. D. Jaffe and C. R. Martinez, "Mexican Consumer Attitudes towards Domestic and Foreign made Products," Journal of International Consumer Marketing, Vol. 7, No. 3, 1995, pp. 7-27. doi:10.1300/J046v07n03 02 
[12] L. A. Heslop and N. Papadopoulos, "But Who Knows Where or When: Reflections on the Images of Countries and Their Products. In: N. Papadopoulos and L. A. Heslop, Eds., Product-Country Images: Impact and Role in International Marketing, International Business Press, New York, 1993.

[13] N. Papadopoulos, L. A. Heslop and J. Beracs, "National Stereotypes and Product Evaluations in a Socialist Country," International Marketing Review, Vol. 7, No. 1, 1990, pp. 32-47. doi:10.1108/02651339010141365

[14] R. Ettenson, "Brand Name and Country of Origin Effects in the Emerging Market Economies of Russia, Poland, and Hungary," International Marketing Review, Vol. 10, No. 5, 1993, pp. 314-336. doi:10.1108/02651339310050057

[15] J. Almonte, C. Falk, R. Skaggs and M. Cardenas, "Country of Origin Bias among High Income Consumers in Mexico: An Empirical Study," Journal of International Consumer Marketing, Vol. 8, No. 2, 1995, pp. 27-44. doi:10.1300/J046v08n02 03

[16] W. Bailey and S. A. G. de Pineres, "Country of Origin Attitudes in Mexico: The Malinchismo Effect," Journal of International Consumer Marketing, Vol. 9, No. 3, 1997, pp. 25-41. doi:10.1300/J046v09n03 03

[17] M. Jordan, "In India, Repealing Reform is a Tough Sell: Leaders Decry Foreign Goods, But Consumers Love Them," In: Wall Street Journal (Eastern Edition), 22 May 1996, p. A18.

[18] D. B. Klenosky, S. B. Benet and P. Chatraba, "Assessing Czech Consumers' Reactions to Western Marketing Practices: A Conjoint Approach," Journal of Business Research, Vol. 6, No. 2, 1996, pp. 189-198. doi:10.1016/0148-2963(95)00121-2
[19] E. Kaynak, O. Kucukemiroglu and A. S. Hyder, "Consumers' Origin (coo) Perceptions of Imported Products in a Homogenous Less-developed Country," European Journal of Marketing, Vol. 34, No. 10, 2000, pp. 12211241. doi:10.1108/03090560010342610

[20] N. Zhou and R. W. Belk, "Chinese Consumer Readings of Global and Local Advertising Appeals," Journal of Advertising, Vol. 33, No. 3, 2004, pp. 63-73.

[21] H. Khan and D. Bamber, "Market Entry Using Country-of-Origin Intelligence in an Emerging Market," Journal of Small Business and Enterprise Development, Vol. 14, No. 1, 2007, pp. 22-35. doi: 10.1108/14626000710727863

[22] V. V. Cordell, "Effects of Consumer Preferences for Foreign Sourced Products," Journal of International Business Studies, Vol. 23, No. 2, 1992, pp. 251-269. doi:10.1057/palgrave.jibs.8490267

[23] C. Okechuku and V. Onyemah, "Nigerian Consumer Attitudes toward Foreign and Domestic Products," Journal of International Business Studies, Vol. 30, No. 3, 1999, pp. 611-622. doi:10.1057/palgrave.jibs.8490086

[24] K. Saffu and J. Walker, "The Country-of-Origin Effects and Consumer Attitudes to Buy Local Campaign: The Ghanaian Case," Journal of African Business, Vol. 7, No. 1-2, 2006, pp. 183-199. doi:10.1300/J156v07n01_09

[25] J. L. Ferguson, K. Q. Dadzie and W. J. Johnston, "Country-of-origin Effects in Service Evaluation in Emerging Markets: Some Insights from Five West African Countries," Journal of Business and Industrial Marketing, Vol. 23, No. 6, 2008, pp. 429-437. doi:10.1108/08858620810894472 